\title{
Teenage Mothers' Socio-Economic Status and Involvement in Their Children's Early Literacy Skills Acquisition in Kilifi, County Kenya
}

\author{
Henry Mugambi Murong’a $^{1} \quad$ Ong’ang'a Hudson Ouko $^{2} \quad$ Bitengo Teresa Mwoma $^{3}$
}

\begin{abstract}
Early literacy competency is a key factor in a child's reading progress, school transition and academic achievement. Children who acquire pre-literacy skills adequately and early in life have been seen to have a smooth transition, have a thorough understanding of concepts in other learning areas and become high academic achievers. Since acquisition of pre-literacy skills is a fundamental issue in the education cycle of an individual, it should not be left to teachers alone. It is of essence to establish how parents can be involved in their children's acquisition of pre-literacy skills since they are the first teachers that a child encounters. Parents can be involved in promoting their children's acquisition of pre-literacy skills by providing resources that promote acquisition of pre-literacy skills, assisting children to do homework, involving children in shared book reading and creating a stimulating Home Learning Environment (HLE). A family's Socio-Economic Status has been identified as one of the major factors that influence the rate of parental involvement in education. Parents from privileged SES backgrounds are more involved in their children's education than their counterparts from low SES backgrounds. Most teenage mothers drop out of school before completing the whole education cycle and therefore they lack marketable skills that would help them get decent jobs. This means that they end up in low paying and unsatisfying jobs. It was therefore important to find out how the SES of teenage mothers influence their involvement in children's acquisition of pre-literacy skills. This article highlights findings from a study that sought to establish the influence of teenage mothers' SES on their involvement in children's acquisition of preliteracy skills. The study was based on Bronfenbrenner's Ecological Systems Theory and employed descriptive survey design. It was carried out in Kilifi County, Kenya and involved a sample of 115 teenage mothers. A questionnaire was used to collect data from respondents. Descriptive statistics were used to analyze data. Findings indicated that the SES of teenage mothers influence their involvement in children's acquisition of preliteracy skills. The authors recommended that the back to school policy should be fully implemented, county governments increase resources allocated to pre-primary schools and donor agents should help teenage mothers acquire vocational skills.
\end{abstract}

Keywords: Demographic factors, early literacy, education level, pre-literacy skills, pre-primary children, socioeconomic status, teenage mothers

DOI: $10.7176 / \mathrm{JEP} / 11-18-15$

Publication date:June 30th 2020

\section{Introduction}

Acquisition of early literacy skills is the foundation of all learning and it influences a child's understanding of concepts in other learning areas taught in school. Chaplain (2012) postulated that learners who acquire preliteracy skills adequately and early in life experience a lot of exposure to print media and advance in a variety of domains of knowledge by the time they reach grade 3. According to Harrison, Goldfield, Metcalfe and Moore (2012) early literacy skills acquired early in life act as requisite skills for academic achievement. Early literacy competence has also been associated with a person's ability to make meaningful contributions in the society later in life. Desmond and Elfert (2008) revealed that early literacy is a useful ingredient in determining whether an individual will contribute in the society or not. Annie (2010) established that children who experience difficulties in their vocabulary during early years, are much more likely to experience later reading difficulties than their peers who acquire early literacy according to the expected milestones. To avert the danger of delayed acquisition of pre-literacy skills by children, it is important to involve parents in their children's acquisition of pre-literacy skills. Muola (2010) suggested that parents can be involved in their children's education by assisting them to do homework, talking to children about school and taking children on field trips. The SES of a family has been identified as one of the major factors that influence parental involvement in education. Ghosh (2013) revealed that parents from high SES backgrounds provide a better Home Learning Environment (HLE) than those from low SES. Similarly, Vellymalley (2012) argued that parents from high SES backgrounds provide more resources such as books and toys for their children than their counterparts from low SES backgrounds. This means that high SES parents are more involved in their children's education than those from low SES backgrounds.

\subsection{Background to Socio-Economic Status of Teenage Mothers}

Though parental SES level greatly influences parental involvement in education (Ghosh 2013; Vellymalley 
2012), most teenage mothers are of low SES levels. Smith (2012) established that most teenage mothers leave school before completing their core education and therefore they do not have marketable skills. Angeline, Rustica, Nerlie, and Ronalissa (2014) found that teenage mothers lack most job qualifications, which means that they are in low paying and often unsatisfying jobs. Almond and Currie (2011) ascribed that teenage mothers may be more resource constrained during their children's early years, a period critical to children's development. Financial constraints experienced by teenage mothers may limit provision of resources that promote acquisition of pre-literacy skills among children such picture/story books. Consequently, children born to teenage mothers are likely to lag behind their peers in acquisition of pre-literacy skills such as letter identification and sound naming.

In spite of the financial challenges experienced by teenage mothers, the number of children born to teenage mothers is on increase. Martin, Hamilton, Osterman, Driscoll and Drake (2018) reported that a total of 194377 babies were born to women aged 15-19 years in the USA in the year 2017, making up a birth rate of 18.8 births per 1000 women. According to the United Nations Population Fund (UNPF, 2013), teenage pregnancy remains a challenge requiring urgent resolution the world over. The World Health Organization (WHO 2020) reported that $11.6 \%$ of all births in the world were due to women aged 15-19 years. Approximately $95 \%$ of teenage pregnancies occur in the developing countries with 36.4 million women becoming mothers before age 18 (UNPF, 2013). Kassa, Arowojolu and Odukogbe (2018) found out that teenage pregnancies in Africa stood at $18.8 \%$. The rate of teenage pregnancy is highest in Eastern Africa $(21.5 \%)$ and lowest in Northern Africa $(9.2 \%)$. The issue of caring for children born to teenage mothers is addressed differently in various parts of the world, with the developed world being a step ahead of the developing nations. In the United Kingdom (UK), parents who want to start a course sponsored by the government and are at the age of 20 years or below are given around 160 pounds every week to cater for their children and travelling up to the time they complete the course (Corlyon \& Stock, 2011). In Ontario, there are free services like early year centers that can help offset the effects of being born into a negative social situation (Morinis, Carson \& Quigley 2013). Ontario early year centers offer children up to the age of six years and their caregivers opportunities to take part in programs and activities together. Some of these programs include early year centers and library programs. These programs are likely to promote early literacy skills among all children, regardless of their socio-economic background.

In the Sub-Saharan Africa, most teenage mothers come from low socio-economic backgrounds and care for their children under very hard circumstances that are not easy to avoid or improve (McDermott, Graham \& Hamilton 2011). Due to extreme poverty, teenage mothers may be unable to provide materials needed for a healthy HLE, making their children lag behind in acquiring pre-literacy skills. The high rate of teenage births in the Sub-Saharan Africa is not accompanied by a substantial government support. Many teenage mothers can barely provide the necessary requirements for their children. For instance, Siebert (2016) reports that in Malawi there is no program aimed at helping teenage mothers and many of them end up in cocoa plantations as casual laborers to keep themselves and their children fed. Being casual laborers, their income might not be sufficient to enable them cater for their daily needs, those of their children and buy items that promote a facilitative HLE such as picture books, story books and toys. This is likely to slow down acquisition of pre-literacy skills among children born to teenage mothers.

In Kenya, pregnancies among school age girls have become so rampant that they have attracted the attention of the Ministry of Education. Nyamai (2018) reports that in 2018, the cabinet secretary in charge of education ordered the ministry's quality assurance team to investigate and file a report of all cases of pregnancies among school girls. This followed reports that many candidates in the 2018 Kenya Certificate of Primary Education sat for their examinations in labor ward. Nyamai (2018) adds that many other girls had given birth prior to the examination day while some others were expectant at the time of sitting for their examinations. The Kenya Demographic Health Survey Report (2014) documents that 15\% of women aged 15-19 years have already had a birth and 3\% are pregnant with their first child. Another study by UWEZO (2015) found out that 34 in 100 children in Kenya were born to teenage mothers. The same study established that school readiness (which preliteracy skills are part of) among children aged under 7 years enrolled in school is low and disparate. A regression analyses showed that the most important variables affecting school readiness were mother's education and poverty of household. Since most teenage mothers are of low education levels and come from low socioeconomic backgrounds Smith (2012), there is a possibility that teenage motherhood has contributed to low acquisition of pre-literacy skills by their children.

In Kilifi County, $21.8 \%$ of women aged 15-19 years have begun child bearing, making it one of the counties with highest cases of teenage pregnancies (Kenya Demographic Health Survey Report 2014). According to Njoka (2016), there is widespread consensus across Kilifi that the issue of teenage pregnancies in the county is pervasive. He adds that public administrators, religious leaders and the general public all agree that it is a problem that requires urgent attention. In a report released by the Children's Affairs Department of Kilifi County and published in the Daily Nation, Lwanga (2018) reports that Kilifi County has one of the highest numbers of teenage pregnancies in the country. The report puts the number of teenagers who got pregnant within the year 
2018 as 13,624 for girls aged 15-19 years and an additional 290 for girls aged 10-14 years. The high number of teenage pregnancies resulting to high number of teenage births means that among the children joining pre-school in Kilifi county, there is a big number of them that is born to teenage mothers. This comes amid reports that $68 \%$ of class 3 pupils in Kilifi County cannot read a class 2 story (Uwezo 2013). There may be a correlation between high rate of teenage motherhood and low acquisition of early literacy skills hence low reading levels.

In Magarini Sub-County, Aseda (2014) reports that at least 360 girls drop out of school every year due to pregnancy. This translates into one child being born to a teenage mother every day. She also reports that these girls come from poor families and it might be difficult for them to take care for their children. It is also possible that these teenage mothers might be unable to provide a healthy HLE for acquisition of pre-literacy skills. Njoka (2016) describes Magarini Sub-county as a hot spot of teenage pregnancies. According to Children's Affairs Department, Kilifi County (2019), there were 2861 children born to teenage mothers in Magarini Sub-County in the year 2018. The number of children born to teenage mothers being this high, it is important to establish how their parents participate in their education and especially acquisition of pre-literacy skills which is the foundation of all learning. Most teenage mothers are lowly educated and come from low socio-economic backgrounds (Njoka 2016). Both socio-economic status and mother's level of education have been found to be positively associated with development of early literacy in children (UWEZO 2015; Mwoma 2017). Consequently, children born to teenage mothers may lag behind their peers in acquisition of early literacy skills. Despite this, the government policy on teenage pregnancy favors teenage mothers over their children. The Kenya back to school policy states that teenage mothers should be allowed back to school after child birth (Omwancha 2012). This means that the children of teenage mothers are taken care of by their grandparents. Most of these grandparents are financially poor and illiterate. They might not be able to provide a healthy HLE that is needed for their grandchildren's acquisition of pre-literacy skills. These children may have challenges in acquisition of preliteracy skills due to a HLE that is not enabling. Though various studies conducted in Kenya (Opiyo 2017; Mogaka 2012; Ouko 2015 and Koech (2010) have all underscored the impact of parental SES on involvement in children's early literacy acquisition, none of them focused on teenage mothers' involvement in their children's acquisition of pre-literacy skills. In a recent study, Murong'a, Mwoma and Ouko (2020) established that teenage mothers in Kilifi County are not adequately involved in their children's education. The current study sought to explore the influence of teenage mothers' SES level on their involvement in children's acquisition of pre-literacy skills.

\subsection{Theoretical Underpinning}

This article is anchored on Bronfenbrenner's Ecological Systems Model (1998). The model focuses on the development of a child in the light of the system of relationships that surround him/her. This theory consists of five complex layers of the surroundings and each layer affects the development of a child. The innermost layer is called the microsystem. It consists of the immediate environment in which the child lives. This may be the home, school, peer group or community. The second layer is the mesosystem. It includes the interactions of different microsystems which a child finds himself/herself in. These may include linkages between home and school, peer group and family or family and church. The third layer consists of exosystems. These are the settings that a child does not have direct contact with but affects him/her, for example, loss of a job by a parent may affect a child. The macrosystem, which is the fourth layer encompasses cultural and societal beliefs and programming that influence a child's development. The fifth and last layer is called the chronosystem. It consists of systematic happenings to an individual such as divorce, death of a family member and other life altering events. The interaction between factors in the child, his/her family, community, surroundings and social structure greatly influence his/her development. It is important to note that conflicts in one layer will ripple out through other layers.

This study focused on the mesosystem layer because it is about teenage mothers' involvement in their children's acquisition of pre-literacy skills. The mesosystem encompasses interactions of the different microsystems which the developing child finds himself/herself in. It is a system of microsystems and involves linkages between different microsystems, for example, the school and the family. In the mesosystem layer, a person's individual microsystems do not function independently but are intertwined and exert influence upon one another. The current study is on teenage mothers' involvement in their children's acquisition of pre-literacy skills. Therefore, the two microsystems involved are home and the school. The relationship between home and school forms the child's mesosystem. The home is the first social construction that a child encounters in life and it plays a great role in promoting development of early literacy skills. This is done through activities such as storytelling, shared book reading and providing resources necessary for promotion of pre-literacy skills such as picture books and toys. If a child's parents get involved in helping children in work related to school, the child's development is affected positively through harmony and like-mindedness. Such a child is likely to easily acquire pre-literacy skills such as letter identification, sound knowledge, oral blending and oral segmentation. On the other hand, if the teenage mothers do not get involved in promoting the activities done in school, the child 
experiences disequilibrium and conflicting thoughts. Such a child may have difficulties in acquiring early literacy skills.

\section{LITERATURE REVIEW}

\subsection{Influence of Parental Socio-Economic Status on Involvement in Children's Education}

Parental socio-economic status (SES) influences their involvement in education. Jednorog, Altarelli, Monzalvo, Fluss and Dubois (2012) defines socio-economic status as a multi-dimensional construct that includes measures of not only material wealth but also education and social prestige. For the purpose of this study socio-economic status is measured in terms of a teenage mother's monthly income. A family's socio-economic status has been linked with parental involvement in provision of a stimulating Home Learning Environment (HLE). According to Evans, Kelley, Sikora and Trieman (2010) parents from higher socio-economic backgrounds are likely to provide higher levels of psychological support for their children through environments that encourage the development of skills necessary at school. A family's socio-economic status may also influence the extent of devotion of parents towards their children's education. According to Dixson, Keltner, Worrel, and Mello (2017) high socio-economic families have much more time, energy and knowledge about education and they are likely to show warmth and affection in order to cultivate a favorable parent relationship. Zhao and Hong (2012) pointed out that high socio-economic parents are likely to be involved in behaviors that support their children's education such as checking homework, discussing school conditions and provision of a rich HLE and this can foster formation of good study habits of children and lead to high academic achievement. In another study, Ankrum (2016) sought to establish whether parental socio-economic status played a role in teacher-parent communication about children's academic performance. He established that parents with higher income communicated with teachers of their children about education than those from lower income backgrounds. In their study, Kuru and Taskin (2016) sought to establish parental involvement in education in terms of their socioeconomic status. They employed interview and document analysis in their qualitative study. The study sample consisted of 11 teachers, 4 administrators working at public and private primary and secondary schools and 6 parents. They also analyzed documents related to the involvement of parents in education such as school newspapers, announcements, news and the activities pages of the schools' website. Results were that parents having a good socio-economic status were more willing and active in participating in education activities. Kuru and Taskin (2016) focused on the influence of socio-economic on parental involvement in primary and secondary schools as opposed to the current study which focused on pre-primary school.

High SES parents have been associated with involving their children in literary rich conversations. TamisLemonda and Rodriguez (2014) conducted a study in the United States and revealed that children from highincome families tend to have more advanced vocabulary compared to their peers from low-income families from as early as three years. They attributed this to high exposure to stimulating activities in high SES families. Ghosh (2013) established a reasonable difference in the HLE between children from low socio-economic families and those from higher socio-economic backgrounds. He observed that children from privileged backgrounds have parents who start up and involve them more in conversations about literacy as early as when they are two and half years old. Ghosh (2013) further observed that parents from the upper social class talk more about literacy in less structured contexts than their counterparts in the low socio-economic backgrounds. This promotes interest in knowing to read and write among children from high socio-economic backgrounds. Opposed to this, talks about immediate daily living dominate engagements between children of low income families and their parents. According to Nelson (2010) conversations in low SES households revolve around basic needs such as food and clothing. This results in children from low SES having very concrete language. According to Lawson (2012), children from low SES backgrounds have the highest chance of lagging behind in acquisition of pre-literacy competences before joining school. Children who come from low SES families portray limited input in terms of volubility and quality of early literacy skills when compared with children from higher SES families (Pruitt \& Oetting, 2009). Consequently, the abstract and decontextualized language used in school becomes hard for children from low SES to understand.

Children from high SES backgrounds are likely to complete the whole education cycle as opposed to those from low SES backgrounds who are likely to drop out of school before completing their education. Marbuah (2016) asserted that children from high income households acquire more years of schooling than children from low income households. High SES parents are more likely to provide more resources that promote acquisition of pre-literacy competences than their low SES counterparts. Muandu, Parsitau and Wambugu (2015) established that high SES parents are involved more than low SES parents in provision of basic needs, provide a better study environment, provide appropriate diet for their children and assist them in learning activities as opposed to low SES parents who are not adequately involved in their children's education. Vellymalley (2012) argues that a parent's socio-economic status plays an important role in providing educational resources. She further adds that parental socio-economic status appears to impose the greatest impact on the child's educational outcomes. Children from high SES have access to more reading materials than children from low SES. Morran (2010) 
established that children living in high SES neighborhoods own an average of 13 books. He also observed that in low SES neighborhoods on average, one book is shared among 300 children. Thomson and De Bortoli (2017) asserted that the number of books at home are one of the most influential factors in a student's academic achievement. Clark (2011) established that children who have books of their own enjoy reading more and read more frequently than children who do not have books of their own. Consequently, children from high SES are likely to read more books and have advanced reading and writing skills while those from low socio-economic backgrounds are most likely to read less books, have difficulties in reading and writing skills and their language becomes very basic and concrete.

Though all these studies (Vellymalley 2012; Kuru and Taskin 2016; Thomson and De Bortoli 2017; TamisLemonda and Rodriguez 2014; Ghosh 2013; Nelson 2010; Lawson 2012 Pruitt \& Oetting 2009; Morran 2010 and Clark 2011) investigated the impact of SES on parental involvement in education, none of them was based on children born to teenage mothers as is the case in this study. Children born to teenage mothers are likely to lag behind their peers in acquiring pre-literacy skills because families started by teenage mothers have been linked with low socio-economic status. The Urban Child Institute (2015) established that families started by young parents from low socio-economic status lack adequate resources, have housing challenges, feed on poor and unbalanced meals, have difficulties in transportation and are likely to have insufficient toys and books for their children. This inhibits adequate exploration and manipulation of environment by their children which in turn limits acquisition of pre-literacy skills. Angeline, Rustica, Nerlie, and Ronalissa (2014) found that teenage mothers lack most job qualifications, which means that they are in low paying and often unsatisfying jobs. This implies that they may not be able to afford adequate resources required for their children's acquisition of preliteracy skills such as story books and picture books. According to Penman-Aguilar, Carter, Snead and Kourtis (2013) teenage motherhood is associated with low education levels, low income levels and low SES. Burges (2005) established that teenage mothers tend to function less effectively in numerous realms than their peers who delay childbearing. He further argued that teenage mothers accorded their children fewer experiences and their children are at a risk of school failure.

Studies carried out in Africa also reveal that there is a relationship between a family's socio-economic status and parental involvement in children's acquisition of pre-literacy skills. In a study carried out in South Africa, Muchuchuti (2015) confirmed that children from high SES families performed better than their counterparts from low SES families because parents from high socio-economic backgrounds were more committed in their children's education than those from low socio-economic backgrounds. After conducting his study in Ethiopia, Eshetu (2015) established that there is a strong relationship between parental socio-economic conditions and their involvement in their children's academic achievement. In another study conducted in Rwanda, Ndarihoranye and Ndayambaje (2012) established that children from high SES performed better than those from low SES in early literacy skills. Ndarihoranye and Ndayambaje (2012) ascribed that parents from high socio-economic backgrounds can provide more resources that promote early learning such as books and play materials while children from low socio-economic background have minimal interactions with materials that promote acquisition of pre-literacy skills. In a survey conducted by UWEZO (2013) in Kenya, Tanzania and Uganda, children were asked to recognize a letter from the alphabet, read a word, read a paragraph and read and understand a story in English. It was reported that children from disadvantaged backgrounds performed worse in literacy than their counterparts from privileged backgrounds.

In Kenya, parental involvement in education has been emphasized. Ouko (2015) advised that for better achievement in early literacy and numeracy active parental involvement is vital. However, low SES among parents has been linked with low involvement in education. In his study, Opiyo (2017) established that low socio-economic households may not be in a position to avail basic literacy resources that support children's reading development such as alphabetical toys, crayons, picture books and pencils. The same households may also fail to be involved in asset based literacy practices such as library visits and family shopping. Children from these families are likely to lag behind their peers in acquiring early literacy skills such as letter recognition, sound naming, oral blending and oral segmentation. Mogaka (2012) conducted a survey in Kisii and found out that among other factors, a family's level of income determines parental involvement and eventually pupils' academic achievement. He established that pupils from high income backgrounds had a higher academic achievement than pupils who came from low income backgrounds. Similarly, Koech (2010) in his study in Uasin Gishu County established that children from high SES backgrounds performed better than those from low SES background. Though there are numerous studies conducted in Kenya on early literacy (UWEZO 2012; Opiyo 2017; Mogaka 2012 and Koech 2010), none of them focused on teenage mothers' involvement in their children's acquisition of pre-literacy skills. The current study intended to fill this gap by investigating teenage mothers' involvement in their children's acquisition of pre-literacy in Magarini Sub-County, Kilifi County. 


\section{0 Research Methodology}

\subsection{Research Design}

This study employed descriptive survey design. The design was selected because the researchers did not intend to manipulate variables but aimed at describing how they affect each other in their natural form. Mugenda and Mugenda, (2003) maintain that descriptive survey is a method of collecting data in order to answer questions concerning the current status of the problem under study without manipulating them. In this study, the researchers intended to establish the extent of teenage mothers' involvement in their children's acquisition of pre-literacy skills as it is without any form of manipulation.

\subsection{Location of the study}

This study was carried out in Magarini Sub-County of Kilifi County. The major town of the Sub-County is Marafa town which is about 42 kilometers from Malindi town. The major economic activities in the area are salt mining and palm wine tapping. Agriculture is also practised but the rains are unreliable. Due to this, poverty levels are very high. It is common to see young school girls being involved in sexual affairs with the palm wine tappers and motorbike operators so as to get food and other basic requirements that their parents are unable to provide. Magarini Sub-County is known for its high prevalence of teenage (Njeru 2016). Very little is known about the education of children born to teenage mothers in the sub-county.

\subsection{Participants}

The participants of this research consisted of 115 teenage mothers who were purposively selected from the study area. The participants had children in either public or private pre-primary school within the study area. The area under study had 180 public pre-primary schools and 30 private pre-primary schools spread in 6 zones as shown on table 1 , out of which 18 public pre-primary schools and 6 pre-primary schools were sampled for the purpose of the study.

Table 1: Sampling Frame

\begin{tabular}{|c|c|c|c|c|c|}
\hline ZONE & $\begin{array}{l}\text { PUBLIC PRE- } \\
\text { PRIMARY } \\
\text { SCHOOLS }\end{array}$ & $\begin{array}{l}\text { SAMPLED PRE- } \\
\text { PRIMARY } \\
\text { SCHOOLS }\end{array}$ & $\begin{array}{l}\text { PRIVATE } \\
\text { PRIMARY } \\
\text { SCHOOLS }\end{array}$ & $\begin{array}{l}\text { SAMPLED PRIVATE } \\
\text { PRE-PRIMARY } \\
\text { SCHOOLS }\end{array}$ & TEENAGE MOTHERS \\
\hline GARASHI & 32 & 3 & 2 & 1 & 12 \\
\hline MARAFA & 50 & 5 & 4 & 1 & 18 \\
\hline GONGONI & 33 & 3 & 8 & 1 & 30 \\
\hline SABAKI & 7 & 1 & 3 & 1 & 10 \\
\hline ADU EAST & 30 & 3 & 5 & 1 & 28 \\
\hline ADU WEST & 28 & 3 & 8 & 1 & 17 \\
\hline TOTAL & 180 & 18 & 30 & 6 & 115 \\
\hline
\end{tabular}

\subsection{Materials}

In this study a questionnaire was used to obtain information from teenage mothers. The questionnaire consisted of 19 questions which were sub-divided into sections A and B. Section A captured demographic information of the respondents such as age at first birth, marital status, education level, occupation and monthly income. Section B captured information on parental involvement in practices and provisions that promote acquisition of preliteracy skills among children such as parents reading for pleasure as models, shared book reading, creating time for children to read and assisting children to do homework.

\subsection{Data Collection Techniques}

Data was collected within a span of one month. During the first two weeks, the researcher visited teachers, pupils and parents so that they familiarize with the nature of the study and see the importance of giving true and accurate information. The parents were also briefed on the questionnaires and informed that their children would take part in the research. During the third week, questionnaires were distributed to parents. They were filled within a span of two weeks. The researcher was always within reach to clarify any issues and he was assisted by respective pre-primary teachers. The questionnaires were collected immediately after being filled.

\subsection{Data analysis}

Data collected were edited, coded and then analyzed quantitatively by use of descriptive statistics. This was done by first re-arranging responses according to the themes and then using frequency counts, percentages and cross tabulations. 


\section{Results and Discussion}

4.1 Influence of Teenage Mothers' Socio-Economic Status on their Involvement in Children's Acquisition of Pre-Literacy Skills

The study sought to establish how teenage mothers' socio-economic status influence their involvement in children's acquisition of pre-literacy skills. The findings were discussed under different themes which include; Marital status of teenage mothers, occupations of teenage mothers, monthly income and the influence of socioeconomic status of teenage mothers on their involvement in children's acquisition of pre-literacy skills.

\subsection{Marital Status of Teenage Mothers}

The researcher intended to establish the marital status of the teenage mothers. The reason for establishing this background variable is because married teenage mothers would probably be supported financially by their husbands thereby providing a better HLE than their single, divorced or widowed counterparts. This would in turn promote their children's rate of acquiring pre-literacy skills. The respondents were required to state whether they were married, divorced, separated, divorced or widowed. The results were as shown on table 2;

Table 2. Marital Status of Teenage Mothers

\begin{tabular}{|l|l|l|}
\hline Marital Status & $\begin{array}{l}\text { Number of Teenage Mothers } \\
(\mathbf{n}=\mathbf{1 1 5})\end{array}$ & Percentage \\
\hline Single & 61 & $53.1 \%$ \\
\hline Married/Cohabiting & 39 & $33.9 \%$ \\
\hline Divorced/Separated & 13 & $11.3 \%$ \\
\hline Widowed & 2 & $1.7 \%$ \\
\hline Total & 115 & 100 \\
\hline
\end{tabular}

According to table 2 above, the majority $(53.1 \%)$ of teenage mothers were also single mothers. The study also established that $33.9 \%$ of the respondents were living with a man either through marriage or cohabiting. It can also be revealed that $11.3 \%$ of the respondents had been in marriage and later divorced/separated and 2 of them $(1.7 \%)$ were widowed. It is evident that the respondents $(51.3 \%)$ were single mothers and $13(11.3 \%)$ were divorced or separated. This puts it to $62.6 \%$ of the respondents who were the sole breadwinners for their children or rely on handouts from the extended families and other well-wishers. Without job skills and a reliable source of income teenage mothers may not be able to provide for their financial needs and those of their children adequately. They may also be unable to provide resources that support acquisition of pre-literacy skills by their children such as story/picture books and toys. Being single mothers may also force teenage mothers to spend a lot of time trying to meet their financial obligations that they may not get adequate time to involve their children in activities that promote acquisition of pre-literacy skills such shared book reading and storytelling. Consequently, their children may lag behind in acquiring pre-literacy skills such as letter identification, sound naming and oral blending. They are also likely to acquire limited vocabulary. The findings of the current study agree with Martin et al (2018) who observed that most teenage mothers are young school girls aged 15-19 years and not yet married. The findings of the current study also concur with the Kenya Demographic Health Survey (2014) which reported that most teenage mothers in the country were unmarried. The current findings are also in agreement with Nyamai (2018) who observed that most school girls in Kenya are impregnated by adults they know and who do not marry them or give any kind of financial support.

\subsection{Occupation of Teenage Mothers}

The authors intended to establish the day to day activities that teenage mothers get involved in so as to earn an income. This was of paramount importance to the study since the kind of activities that one does may influence their earnings. The authors aimed at establishing how these earnings of teenage mothers in turn influenced their involvement in children's acquisition of pre-literacy skills. Teenage mothers were asked to state their daily activities and the results were as shown on table 3;

Table 3. Occupations of Teenage Mothers

\begin{tabular}{|l|l|l|}
\hline Occupation & $\begin{array}{l}\text { Number of Parents } \\
(\mathbf{n = 1 1 5})\end{array}$ & Percentage \\
\hline Formal Employment & 2 & $1.7 \%$ \\
\hline Business & 6 & $5.2 \%$ \\
\hline Casual Laborers & 43 & $37.4 \%$ \\
\hline House wife/No job & 64 & $55.7 \%$ \\
\hline Total & 115 & 100 \\
\hline
\end{tabular}

Table 3 above shows that a great majority of teenage mothers $(55.7 \%)$ had no jobs and relied on other people such as relatives and spouses for a livelihood and upkeep of their children. It also shows that $37.4 \%$ of the respondents relied on casual jobs such as washing clothes at a fee and gardening to earn a living and meet their 
children's financial needs. The study also revealed that only $5.2 \%$ of the respondents were involved in business. The number of teenage mothers in formal employment was almost negligible (1.7\%). It is clear that most teenage mothers did not have any form of employment (55.7\%) or were casual laborers (37.4\%). The number of unemployed teenage mothers and those in casual employment being this high $(55.7 \%$ and $37.4 \%$ respectively) means that their earnings are meagre and they may not be able to meet their financial obligations sufficiently and provide materials that are needed for their children's development of pre-literacy skills such as story books and alphabetical toys. As a result, children born to teenage mothers are likely to lag behind their peers in acquisition of pre-literacy skills

The findings of the current study are similar to those of Smith (2012) who established that since teenage mothers have not completed core education and do not have marketable skills, they end up doing casual work. The current findings are also similar to those of Siebert (2016). Siebert (2016) established that most teenage mothers do not have decent jobs and they end up in cocoa plantations as casual laborers to keep themselves and their children fed. The findings of the current study also concur with those of Angeline et al (2014). Angeline et al (2014) found that teenage mothers lack most job qualifications, which means that they are in low paying and often unsatisfying jobs

\subsection{Monthly income of Teenage Mothers}

The study sought to establish the monthly earnings of the teenage mothers. This was important to the study since socio-economic status (SES) of the teenage mothers was measured in terms of their monthly earnings and the researcher intended to establish whether the SES of teenage mothers influence their involvement in children's acquisition of pre-literacy skills. The respondents were asked to state their monthly income as either level 1 (Kshs 0-5000), level 2 (Kshs 5001-10000), level 3 (10001-15000) or level 4 (Kshs above Kshs 15000). Teenage mothers in levels 1 and 2 were termed to as lower SES respondents and those in levels 3 and 4 higher SES respondents. Results were as shown on table 4;

Table 4. Monthly Income of Teenage Mothers

\begin{tabular}{|l|l|l|l|}
\hline Monthly Income (in Kshs) & SES LEVEL & $\begin{array}{l}\text { Number of Teenage Mothers } \\
(\mathbf{n}=\mathbf{1 1 5})\end{array}$ & Percentage \\
\hline $\mathbf{0 - 5 0 0 0}$ & 1 & 69 & $60.0 \%$ \\
\hline $\mathbf{5 0 0 1 - 1 0 0 0 0}$ & 2 & 23 & $20.0 \%$ \\
\hline $\mathbf{1 0 0 0 1 - 1 5 0 0 0}$ & 3 & 15 & $13.0 \%$ \\
\hline Above 15000 & 4 & 8 & $7.0 \%$ \\
\hline Total & & 115 & 100 \\
\hline
\end{tabular}

Table 4 above shows that the majority $(60 \%)$ of teenage mothers earned a monthly income of five thousand shillings or below and only $23(20 \%)$ respondents earned between Sh5001 and Sh10000. The study also established that $13 \%$ of the respondents earned between Sh10001 and Sh15000. The number of teenage mothers earning Sh15000 and above a month was almost negligible (7\%). It is evident that the majority of the respondents were in the lower SES levels $(60 \%$ in level 1 and $20 \%$ in level 2$)$ while only a small percentage $(20 \%)$ of the respondents was in the higher SES levels (13\% in level 3 and $7 \%$ in level 4). Low income is most likely to have a negative influence into a child's development of pre-literacy skills since it denies the teenage mothers the ability to provide resources that are necessary for development of pre-literacy skills such as alphabetical toys and writing materials. When pre-primary pupils lack materials such as alphabetical toys and writing materials they are likely to have delayed acquisition of pre-literacy skills and they may have problems in reading. The findings of the current study are in tandem with those of Penman-Aguilar et al (2013) who revealed that teenage motherhood is associated with low education levels, low income and low SES levels. The findings of the current study also concur with those of Angeline et al (2014) who pointed out that teenage mothers lack most job qualifications which means that they are in low paying jobs. The findings of the current study are also in tandem with Urban Child Institute (2015). According to Urban Child Institute (2015) families started by young parents from low socio-economic backgrounds lack adequate resources and have housing challenges.

4.5.1 Influence of Socio-Economic Status of teenage mothers on their involvement in children's acquisition of pre-literacy skills

The researcher intended to establish whether the socio-economic status (which was measured in terms of monthly income) of teenage mothers influence their involvement in children's acquisition of pre-literacy skills. The respondents were asked to state the degree to which they agreed/disagreed that financial constraints limit their involvement in children's acquisition of pre-literacy skills. It was also explained to them that adequate involvement in promotion of acquisition of pre-literacy skills involved provision of adequate story/picture books, purchase/innovation of play materials, providing adequate writing materials, providing a good study area for the child and involving the child in literally rich conversations. The responses expected were; strongly agree, agree, not sure, disagree and strongly disagree. The responses were as on table 5. 
Table 5. Influence of SES level on Parental Involvement

\begin{tabular}{|l|l|l|}
\hline Degree of Agreement/Disagreement & $\begin{array}{l}\text { Number of Parents } \\
(\mathbf{n = 1 1 5})\end{array}$ & \multicolumn{1}{|c|}{ Percentage } \\
\hline Strongly Agree & 64 & $55.7 \%$ \\
\hline Agree & 32 & $27.8 \%$ \\
\hline Not Sure & 7 & $6.1 \%$ \\
\hline Disagree & 8 & $7.0 \%$ \\
\hline Strongly Disagree & 4 & $3.5 \%$ \\
\hline Total & 115 & $100 \%$ \\
\hline
\end{tabular}

The picture depicted on table 5 is that the majority $(55.7 \%)$ of the respondents strongly agree that their low income inhibits them from being adequately involved in their children's acquisition of pre-literacy skills. A further $27.8 \%$ agree that their income impedes them from being adequately involved in promoting their children's acquisition of pre-literacy skills while $6.1 \%$ of the respondents said that they were not sure whether their monthly income influenced their involvement in their children's acquisition of pre-literacy skills. A small number $(7 \%)$ of the respondents disagreed and even a smaller number $(3.5 \%)$ strongly disagreed that their monthly income inhibits their involvement in their children's acquisition of pre-literacy skills. The fact the number of respondents who either strongly agreed $(55.7 \%)$ or agreed $(27.8 \%)$ that their monthly income limits their involvement in their children's acquisition of pre-literacy skills was higher than the number of respondents who disagreed $(7 \%)$ or strongly disagreed $(3.5 \%)$ shows that the monthly income (used to measure SES) of a teenage mother influences her involvement in her child/children's acquisition of pre-literacy skills. Teenage mothers of higher SES levels are likely to be more involved in practices and provisions that promote acquisition of pre-literacy skills such as provision of story/picture books, writing materials and involve their children in literally rich conversations. Consequently, their children are likely to acquire pre-literacy skills such as increased vocabulary, sound and letter naming earlier and faster than their counterparts. On the other hand, teenage mothers of lower SES status are likely to have difficulties in providing resources that promote their children's acquisition of pre-literacy skills such as story/picture books and play materials. As a result, children of lower SES mothers are likely to lag behind their peers in acquisition of pre-literacy skills such as letter and sound naming.

The findings of the current study are in line with those of Almond and Currie (2011) who established that teenage mothers may be more resource constrained during their early years, a period of critical development to their children. The findings of the current study are also in tandem with Burges (2005) who argued that teenage mothers do not provide adequate experiences and resources for their children's developmental needs. The findings of the current study are in tandem with those of Dixson et al (2017) who established that high SES families have more resources and knowledge about education than low SES families and they do not find financial constraints to be an impediment in providing learning resources to their children. The current findings are also in line with those of Kuru and Taskin (2016) who established that parents having a good socio-economic status were more willing and active in participating in education activities. Similar findings were also posted by Vellymalley (2012). In her study, Vellymalley (2012) found that parents' socio-economic status plays an important role in providing education resources. These findings are also similar to those of Opiyo (2017). In his study, Opiyo (2017) established that low socio-economic households may not be in a position to avail basic literacy resources that support children's reading development such as alphabetical toys, picture books and crayons. The findings of the current study are also similar to those of Mogaka (2012). In his study conducted in Kisii Kenya, Mogaka (2012) established that there is a strong relationship between parental SES and their involvement in education.

\section{CONCLUSION}

The study sought to establish the influence of teenage mothers' SES level on their involvement in children's acquisition of pre-literacy skills. It was established that most teenage mothers are of low SES levels and this limits their involvement in children's acquisition of pre-literacy skills. The study also established that most teenage mothers are also single parents and sole bread winners in their families and that a high number of teenage mothers is in casual or not in any form of employment. This means that their earnings are meagre and barely enough to meet their needs and those of their children. This in turn limits their involvement in providing adequate resources that promote children's acquisition of pre-literacy skills such story books and alphabetical toys. Consequently, children born to teenage mothers are likely to lag behind their peers in acquisition of preliteracy skills such as letter identification, sound naming and oral blending.

\section{RECOMMENDATIONS}

Since the study established that most teenage mothers lack marketable skills and are either casual laborers or house wives, the authors recommended that the back to school policy should be fully implemented, whereby 
teenage mothers can go back to school after child birth. The authors also recommended that the county governments and donor agents should help teenage mothers who have at least completed their primary school education to acquire vocational courses such as tailoring and hairdressing. The study also The study also revealed that most teenage mothers are low income earners and cannot provide adequate learning resources for their children. The authors therefore recommended that the county governments should increase resources allocated to pre-primary schools. and donor agents should help teenage mothers acquire vocational skills.

\section{REFERENCES}

Almond, D. \& Currie, J. (2011). Killing Me Softly: The Fetal Origins Hypothesis. Journal of Economic Perspectives, 25, 153-172

Angeline, M., Rustica, V., Nerlie, S. \&Ronalissa, G. (2014). Lived Experiences of Early Pregnancy among Teenagers: A Phenomenological Study. European Scientific Journal,10, (2)446-492, 2014

Ankrum, R. (2016). Socio-Economic Status and its Effects on Teacher/Parent Communication in Schools. Journal of Education and Learning. 5(1), 167-175

Annie, E. (2010). Early Warning: Why Reading by the End of Third Grade Matters. Baltimore, M.D., USA: Annie E. Casey Foundation

Aseda, R. (2014). Tackle Teenage Pregnancies to spur Development. Rural Reports Dec 17th 2014. Retrieved from, https://ruralreporters.com/kenya-tackle-teenage-pregnancies-to-spur-development/

Brofenbrenner, U. (1990). Discovering What Families do. In Rebuilding the Nest: A New Commitment to the American Family. Family Service America as in Berk, L. (2000). Child Development (5th ed). Boston: Allyn and Bacon

Burges, S. (2005). The Pre-School Home Literacy Environment Provided by Teenage Mothers. Journal of Early Child Development and Care, 175(3), 249-258

Chaplain, R. (2012). Parents Helping their Children to Read: The Effectiveness of Paired Reading and Hearing Reading in Developing in a Developing Country Context, Journal of Early Childhood Literacy, 13(4) 471500

Clarke, B. (2014). Parent and Teacher Rating Scales in the Evaluation of Attention Deficit Hyperactivity Disorder: Contribution to Diagnosis in Clinically Referred Children. Journal of Development and Behavioral Pediatrics, 27, (3), 209-218

Corlyon, J. \& Stock, L. (2011). Teenage Parenting Reference Manual. London: Institute of Home Relations.

Dixson, D., Keltner, D., Worrell, F. \& Mello, Z. (2017). The Magic of Hope: Hope Mediates the Relationship Between Socio-Economic Status and Academic Achievement. Journal of Academic Research, 111(4), 507515

Desmond, S. \& Elfert, M. (2008). Family Literacy Experiences from Africa and Around the World. Paris: Institute of International Co-operation of German Adult Education Association.

Eshetu, A. (2015). Parental Socio-Economic Status as a Determinant Factor of Academic Performance of Students in Regional Examination: A Case of Dessie Town, Ethiopia. Africa Educational Research Journal, 3 (4) 221-229, 2015

Evans, M.D., Kelley, J., Sikora, J. \& Trieman, D. (2010). Family Scholarly Culture and Environmental Success: Books and Schooling in 27 Nations. Research in Social Stratification and Mobility. 28(2), 171-197

Ghosh, D. (2013). Socioeconomic Status Links to Children's Literacy Development. Washington University Research Digest. 9(1) :263-274

Harrison, J.L. Goldfeld, S., Metcalfe, E \& Moore, T. (2002). Closing the gap: Early learning programs that promote children's development and Educational Outcomes. Clearinghouse: Australian Government, Australian Institute of Health and Welfare \& Australian Institute of Family Studies.

Isaacs, J. \& Magnuson, K. (2011). Income and Education as Predictors of Children's School Readiness. Washington, D.C.: Brookings Institution

Jednorog, K., Altarelli, I. Monzalvo, K., Fluss, J. and Dubois, J. (2012). The influence of socioeconomic status on children's Brain Structure. $\quad$ Retrieved https://books.google.co.ke/books?id=_tlCDwAAQBAJ\&pg=PA490\&lpg=PA490\&dq=Jednorog,+K.,+Altar elli, + I.+Monzalvo, + K., + Fluss,,$+\mathrm{J} .+$ and + Dubois, $+\mathrm{J} .+(2012) .+$ The + influence + of + socioeconomic + status + on +

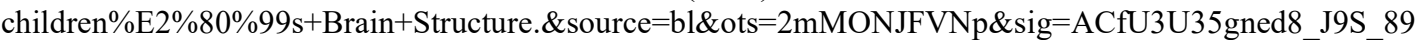
RcyG_snXEj1gbg\&hl=en\&sa=X\&ved=2ahUKEwjvhafmyf7pAhUSyoUKHbUxAoIQ6AEwA3oECAkQA $\mathrm{Q} \# \mathrm{v}=$ onepage \&q=Jednorog $\% 2 \mathrm{C} \% 20 \mathrm{~K} . \% 2 \mathrm{C} \% 20$ Altarelli $\% 2 \mathrm{C} \% 20 \mathrm{I} . \% 20 \mathrm{Monzalvo} \% 2 \mathrm{C} \% 20 \mathrm{~K} . \% 2 \mathrm{C} \% 20 \mathrm{Fl}$ uss $\% 2$ C $\% 20 \mathrm{~J} . \% 20$ and $\% 20$ Dubois $\% 2 \mathrm{C} \% 20 \mathrm{~J} . \% 20$ (2012).\%20The\%20influence $\% 20$ of $\% 20$ socioeconomic $\%$ 20 status $\% 20$ on $\% 20$ children $\%$ E2\%80\%99s\%20Brain $\% 20$ Structure.\&f $=$ false

Kassa, G. M., Arowojolu, A. O. \& Odukogbe, A. A. (2018). Prevalence and Determiners of Adolescent Pregnancy in Africa: A systematic Review and Meta-Analysis. 15, 195-197

Kenya Demographic Health Survey (2014). Working for a World Free Poverty. Nairobi: Kenya National Bureau 
of Statistics

Koech, (2010). Parent-Teacher Partnerships for Enhancing Pre-School Children's Education in Uasin Gishu District. Unpublished PhD Thesis, Kenyatta University

Kuru, S. \$ Taskin, P. (2016). Parent Involvement in Eurasian in Terms of their Socio- Economic Status. Eurasian Journal of Educational Research, 66, 105-122

Lwanga, C. (2018 November 7). Finger Pointing as Kilifi Reports 14000 Teenage Pregnancies. Daily Nation, Retrieved from https://www.nation.co.ke/counties/kilifi/Alarm-asKilifi-reports-14-000-teen-pregnancies/1183282-4837642-c992bhz/index.html

Manduku, J. (2017). Influence of Parental Participation on Academic Performance Among Children in Early Childhood Development and Education Centers Waldai Zone, Kericho County, Kenya. International EJournal of Advances in Education, 3 (7), 199208

Marbuah, D. (2016). Influence of Parental Income and Educational Attainment on Children's Years of Schooling: Case of Ghana. Masters' Thesis. Uppsala University.

Martin, J. A., Hamilton, B. E., Osterman, M, J., Driscoll, A. K. \& Drake, P. (2017). Births: Final Data for 2017 National Vital Statistics Reports: National Centre for Disease Control and Prevention. 67, (8), 55-69, 2018

McDermott, E., Graham, H. \& Hamilton, V. (2011). Experiences of Being a Teenage Mother in the UK: A Report of a Systematic Review of a Qualitative Studies. Lancaster: Lancaster University

Mogaka, M.M. (2012). Influence of Parents' Socio-Economic Status on the Children's Performance in KCPE (2007-2010). A Case of Keumbu Division, Kisii County, Kenya. Unpublished M.ed Thesis. Kenyatta University.

Morinis, J., Carson, C. \& Quigley (2013). Effects of Teenage motherhood on cognitive outcomes in Children: A population based cohort. Archives of Disease in Childhood. Journal of Child Psychology, 98 (3):959-964

Morran, E., (2010). Environmental Social Science: Human - Environmental Interactions and Sustainability. Hobken, N. J," Blackwell publishers.

Muandu, J., Parsitau, D. \& Wambugu, P. (2015). Influence of Parents' Economic Status on Girls' Academic Performance in Mixed Day Secondary Schools. American Journal of Educational Research, 3(11), 1359. 1363

Muchuchuti, M. (2015). The Influence of Parental Involvement on the Learning Outcomes of their Children: A case of Primary Schools in Matebeleland Regions. Journal of Research and Method in Education, 5 (6) 2232

Muola, J.M. (2010). A study of the Relationship Between Academic Achievement, Motivation and the Home Environment Among Standard Eight Pupils. Educational Research and Reviews, 5(5) 213-217

Muronga, H., Mwoma, T. \& Ouko, H. (2020). Teenage Mothers Involvement in their Children's Acquisition of Pre-Literacy Skills: A Case of Kilifi County, Kenya. European Journal of Education Studies, 7(3) 298-317

Mwoma, T. (2017). Children's Reading Ability in Early Primary School Reading: Challenges of a Kenyan Rural Community. Issues in Educational Research, 27(2), 347-364

Ndarihoranye, E. \& Ndayambaje, D. (2012). Socio-Economic Problems Affecting Early Childhood Education, Kigali: KIE

Nelson, N. (2010). Language and Literacy Disorders: Infancy Through Adolescence. Boston: Pearson Education

Njoka, J. (2016). Teenage Pregnancy in Kilifi County of Kenya, Nairobi: Faith to Action.

Nyamai, F. (2018, November 1). CS Amina Orders Probe as Girls Deliver During Exams, Daily Nation, Retrieved from https://www.google.com/amp//s/www.nation.co.ke/news/CS- orders-probe-onteenpregnancies/1056-4832262-view-asAMP-xhm1kkz/index.html

Omwancha, K. (2012). The Implementation of an Educational Re-entry Policy for Girls after Teenage Pregnancy: A Case Study of Public Secondary Schools in Kuria District, Kenya PhD Thesis, Victoria University of Wellington.

Opiyo, R. (2017). Home Literacy Environment and Development of Early Literacy Abilities of 34-Year-Old Children in Kakamega Central Sub-County, Kenya, (PhD Thesis, Kenyatta University)

Ouko, H. (2015). Determinants of Standard One Pupils Achievement in Literacy and Numeracy in Gucha District, Kisii County Kenya. PhD Thesis, Kenyatta University, Kenya

Penman-Aguilar, A., Snead, M. and Kourtis, A. (2013). Social Economic Disadvantage as a Social Determinant of Teen Child-Bearing in the US. Atlanta: Centre for Disease Control and Prevention, https://www.ncbi.nlm.nih.gov/pmc/articles/pmc3562742/\#! po=72.2973

Pruitt, S. L., \& Oetting, J.B. (2009). Past Tense Marking by African American English -speaking children reared in poverty. Journal of speech, Language and Hearing Research,52, 2-15

Raising Children (2014). The Australian Parenting Website https://raisingchildren.net.au/grown-ups/familydiversity/parents-like-me/parenting-as-a-teen

Siebert, V. (2016 January 7). The girls who had to grow up too soon: Heart-Wrenching Photos Spotlight, the 
Plight of Teen Mothers in Africa who are Forced to Care for Babies when they are still just Children themselves, Daily Mail, Retrieved on 16/10/2018 from, https://www.google.com/amp/s/www.dailymail.co.uk/femail/article3389289/amp/The-girls-grow-soonHeart-wrenching-photo-series-spotlightsplight-teen-mothers-Africa-forced-birth-babies-just-childrenthemselves.html.

Smith, W. (2012). Financial problems faced by teen mothers. Prezzi.com. Retrieved from https://prezi.com/ps8rwbxltyum/financial-problems-faced-by-teen-mothers

Tamis-Lemonda, C. \& Rodriguez, E. (2014). Parents' Role in Fostering Young Children's Learning and Language Development. New York: New York University

The Urban Child Institute (2015). Children do better when they are not raised by children. Retrieved from www.urbanchildinstitute.org/articles/researchpolicy/overviews/children- do-better-when-they-are-notraised-by-children

Thomson, S., De Bortoli, 1., \& Underwood, C. (2017). PISA 2015: Australia's Results. Melbourne: Acer Press

UNICEF (2016). Young People and Family Planning: Teenage Mothers. Retrieved from https://limun.org.uk/FCKfiles/File/2016 UNICEF Guide.pdf.

United Nations Population Fund (2013). Motherhood in Childhood: Facing the Challenge of Adolescent Pregnancy. New York, UNFPA. https:/www.unfpa.org/news/teen-mothers-kenya-become-powerfuladvocates-change

UWEZO Assessment Report (2013). Are Our Children Learning? Annual Learning Assessment Kenya 2013: Summary and Key Findings. UWEZO East Africa (2015). Annual learning assessment report in 2014: Are our children learning? Downloaded from https:/www.twaweza.org/go/uwezo-kenya-2015-ala

Vellymalley, S. (2012). Parental Involvement at Home: Analyzing the Influence of Parents Socio-Economic Status. Studies in Sociology of Science, 3(1), 1-6

Zhao, Y. \& Hong, Y. (2012). Social Capital and Education Attainment: A Perspective of Social Network, Resources and Social Closure. Journal of Sociological Study, 42(5) 47-68 